\title{
Essentialism and Anti-Essentialism in Feminist Philosophy
}

\author{
Alison Stone \\ The heated feminist debates over 'essentialism' of the 1980s and early 1990s have largely \\ died away, yet they raised fundamental questions for feminist moral and political philosophy \\ which have still to be fully explored. Centrally at issue in feminist controversies over \\ essentialism was whether there are any shared characteristics common to all women, which \\ unify them as a group. Many leading feminist thinkers of the 1970s and 1980s rejected \\ essentialism, particularly on the grounds that universal claims about women are invariably \\ false and effectively normalise and privilege specific forms of femininity. However, by the \\ 1990s it had become apparent that the rejection of essentialism problematically undercut \\ feminist politics, by denying that women have any shared characteristics which could \\ motivate them to ask together as a collectivity. An 'anti-anti-essentialist' current therefore \\ crystallised which sought to resuscitate some form of essentialism as a political necessity for

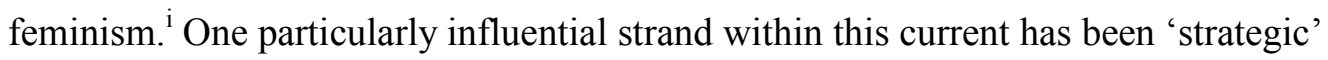 \\ essentialism, which defends essentialist claims just because they are politically useful. In this \\ paper, I aim to challenge strategic essentialism, arguing that feminist philosophy cannot avoid \\ enquiring into whether essentialism is true as a descriptive claim about social reality. I will \\ argue that, in fact, essentialism is descriptively false, but that this need not undermine the \\ possibility of feminist activism. This is because we can derive an alternative basis for \\ feminist politics from the concept of 'genealogy' which features importantly within some \\ recent theoretical understandings of gender, most notably Judith Butler's 'performative' \\ theory of gender.
}

To anticipate, I will develop my argument for a 'genealogical' and anti-essentialist recasting of feminist politics in the following stages. I begin by reviewing the history of 
feminist debates surrounding essentialism, identifying in these apparently highly disparate debates a coherent history of engagement with an 'essentialism' that carries a relatively unified sense. My overview of these debates will trace how anti-essentialism came to threaten feminism both as a critique of existing society and as a politics of change. I shall then assess two attempts by feminist thinkers to surmount the problems posed by anti-essentialism without reverting to the idea that all women share a common social position and form of experience. These attempts are, firstly, strategic essentialism and, secondly, Iris Marion Young's idea that women comprise not a unified group but an internally diverse 'series'. Both these attempts, I shall argue, are unsatisfactory, because they continue tacitly to rely on a descriptive form of essentialism, even as they explicitly repudiate it. Nonetheless, Young's rethinking of women as a series is important in indicating that we need to overcome the problems generated by anti-essentialism by reconceiving women as a specifically non-unified type of social group. Building on this point, I shall argue that feminists could fruitfully reconceive women as a particular type of non-unified group: a group that exists in virtue of having a genealogy. The concept of genealogy, as I understand it, provides a way to reject essentialism (and so to deny that women have any necessary or common characteristics) while preserving the idea that women form a distinctive social group.

My project of reconceiving women as having a genealogy is loosely derived from Judith Butler, whose declared aim in Gender Trouble is to outline a 'feminist genealogy of the category of women'. ii By briefly tracing out the Nietzschean background to recent feminist appropriations of the concept of genealogy, I will suggest that women always become women by reworking pre-established cultural interpretations of femininity, so that they become located - together with all other women - within a history of overlapping chains of interpretation. Although women do not share any common understanding or experience of femininity, they nevertheless belong to a distinctive social group in virtue of being situated 
within this complex history. This rethinking of women as having a genealogy entails a concomitant rethinking of feminist politics as coalitional rather than unified. According to this rethinking, collective feminist activities need not be predicated on any shared set of feminine concerns; rather, they may arise from overlaps and indirect connections between women's diverse historical and cultural situations. I hope that my exploration will begin to show how a genealogical rethinking of women could enable feminists to oppose (descriptive) essentialism while retaining belief in women as a group with a distinctive, and distinctively oppressive, history - an ongoing history which is an appropriate target of social critique and political transformation.

\section{Feminist debates around essentialism}

The first step towards any defence of an anti-essentialist, genealogical, perspective within feminist philosophy is to recall what was centrally at issue in the controversies over essentialism which dominated much 1980s and 1990s feminist writing. Identifying any central themes within feminist discussion of essentialism is complicated, though, as this discussion contains a bewildering variety of strands. Given this variety, the notion of essentialism itself has taken on a correspondingly wide range of meanings for feminists, leading some commentators, such as Gayatri Spivak, to conclude that 'essentialism is a loose tongue' ${ }^{\text {iii }}$ Reviewing the huge body of literature on this question, Cressida Heyes has highlighted four different senses of 'essentialism', all regularly criticised within feminist discussion: (1) metaphysical essentialism, the belief in real essences (of the sexes) which exist independently of social construction; (2) biological essentialism, the belief in real essences which are biological in character; (3) linguistic essentialism, the belief that the term 'woman' has a fixed and invariant meaning; and (4) methodological essentialism, which encompasses approaches to studying women's (or men's) lives which presuppose the 
applicability of gender as a general category of social analysis. Heyes suggests that the first two 'forms of essentialism [which are] premised on metaphysical realist claims about presocial truths have been marginalized within the typology of essentialism', and that feminists have most regularly addressed and opposed methodological essentialism. ${ }^{\text {iv }}$

Heyes' typology helpfully the range of possible varieties of essentialism, but, because she introduces precise distinctions into the 'essentialism' which feminists have generally discussed and criticised as a relatively unified phenomenon, her account obscures how feminist debates around essentialism have actually developed. Despite the variety of strands within these debates, retrospectively they can be seen to be engaged with an 'essentialism' which has a relatively unitary meaning, deriving from the traditional philosophical understanding of essentialism. This relatively unitary sense of essentialism gives feminist debates a coherent history, within which different contributions can be recognised to interweave with and build upon one another. To support this assertion, I shall briefly reconstruct this history, starting from the philosophical sense of essentialism which forms the point of departure for feminist explorations.

Philosophically, essentialism is the belief that things have essential properties, properties that are necessary to those things being what they are. Recontextualised within feminism, essentialism becomes the view that there are properties essential to women, in that any woman must necessarily have those properties to be a woman at all. So defined, essentialism entails a closely related view, universalism: that there are some properties shared by, or common to, all women - since without those properties they could not be women in the first place. Essential properties, then, are also universal. 'Essentialism' as generally debated in feminist circles embraces this composite view: that there are properties essential to women and which all women (therefore) share. ${ }^{\mathrm{v}}$ 
It is notable that, on this definition of the 'essentialism' with which feminists have been concerned, the properties that are essential and universal to all women can be either natural or socially constructed. This is reflected in that critics of essentialism from the later 1980s and 1990s typically attack any view that ascribes necessary and common characteristics to all women, even if that view identifies those characteristics as culturally constructed. Equally, though, it must be acknowledged that feminist thinkers often use 'essentialism' and 'biological essentialism' as interchangeable terms (apparently precluding the possibility that essential characteristics of women could also be cultural). There is an obvious reason for this elision: if there are properties necessary to and shared by all women, these properties, qua necessary, can most be readily identified as natural. Thus, essentialism easily slides into biological essentialism because women's necessary properties are most readily identified as biological.

Such simple, biological, essentialism was commonly held prior to second wave feminism, typically as the view that all women are constituted as women by their possession of wombs, breasts, and child-bearing capacity. Arguably, this view played a crucial ideological role in justifying women's confinement to the domestic sphere as natural and necessary. Second wave feminists therefore opposed essentialism in its pre-feminist, biological, incarnation. However, feminist antipathy to essentialism rapidly extended to elements of biological essentialism perceived to persist within feminism. In the 1970s, socialist feminists criticised the essentialism they detected in the work of some radical feminists who urged revaluation of women's allegedly natural features, such as their childbearing capacity. ${ }^{\mathrm{vi}}$ Within these socialist feminist critiques, (biological) 'essentialism' was typically contrasted to 'social constructionism', which relies on the distinction between biological sex and social gender. On the social constructionist view, sexed biology is both different from, and causally inert with respect to, gender - an individual's socially acquired 
role and sense of identity. So, while being female may require certain anatomical features, being a woman is something different, dependent on identification with the feminine gender the social traits, activities, and roles that make up femininity. Following this recognition of the gap between gender and sex, social constructionists could reject biological essentialism for confusing these two levels of analysis and consequently making a fallacious - and ideologically motivated - attempt to read off the contingencies of social arrangements from the necessities of biology.

Despite repudiating biological essentialism, many influential feminist theorists of the 1970s and early 1980s went on to endorse non-biological forms of essentialism. Having identified femininity as socially constructed, these theorists sought to identify an invariant set of social characteristics which constitute femininity and which all women, qua women, share. Possibilities included women's special responsibility for domestic, affective, or nurturant labour (as Nancy Hartsock argued), their construction as sexual objects rather than sexual subjects (according to Catherine MacKinnon), or their relational, contextual and particularist style of ethical and practical reasoning (for Carol Gilligan). ${ }^{\text {vii }}$ My claim that theorists such as MacKinnon are essentialists might sound odd, given the frequent contrast between essentialism and social constructionism. Yet social constructionists can readily be essentialists if they believe - as do these influential feminist theorists - that a particular pattern of social construction is essential and universal to all women.

Moreover, in the later 1980s, a large number of feminist thinkers began to attack the positions of Gilligan, MacKinnon, and others as - precisely - essentialist. These critics argued, in considerable detail, that universal claims about women's social position or identity are invariably false. It cannot plausibly be maintained that women's experiences have any common character, or that women share any common location in social and cultural relations, or sense of psychic identity. Essentialism, then, is simply false as a description of social 
reality. Moreover, critics pointed out that the descriptive falsity of essentialism renders it politically oppressive as well. The (false) universalisation of claims about women in effect casts particular forms of feminine experience as the norm, and, typically, it is historically and culturally privileged forms of femininity that become normalised in this way. Essentialist theoretical moves thereby end up replicating between women the very patterns of oppression and exclusion that feminism should contest. This point has been pressed particularly forcefully by Elizabeth Spelman, whose classic critique Inessential Woman castigates recurring tendencies within feminism to take certain privileged women's experiences or situations as the norm. ${ }^{\text {viii }}$

One might wonder whether we could defend essentialism without postulating any social or cultural characteristics common to all women if we instead identified women's essential properties with their biologically female characteristics. This need not entail returning to the traditional, misleadingly anatomical, definition of womanhood: one might hold that femininity is socially constructed in diverse ways, but that all these constructions are united in that they build upon and interact with individuals' biologically female characteristics. This option was foreclosed by feminist philosophies of embodiment which developed in the 1990s. Judith Butler, Moira Gatens, and Elizabeth Grosz, in particular, argued that bodies are thoroughly acculturated, and therefore participate in the same diversity as the social field that they reflect. ${ }^{\mathrm{ix}}$ These thinkers argued that our bodies are first and foremost the bodies that we live, phenomenologically, and the way we live our bodies is culturally informed and constrained at every point. Sexed embodiment is therefore not external but internal to the gendered realm of social practices and meanings. Consequently, one cannot appeal to any unity amongst female bodies to fix the definition of women, since the meaning of bodies will vary indefinitely according to their socio-cultural location. 
Following this recognition of the cultural character of bodies, a growing number of theorists in the 1990s rejected the previously popular essentialism/constructionism antithesis. They argued that constructionism remains unduly close to essentialism, since it accepts the existence of natural bodily properties but simply denies them any role in constituting the essence of woman. According to these critics, constructionism remains problematic because, in retaining the belief in natural properties of female bodies, it leaves permanently open the possibility of making a (spurious) appeal to these properties in the attempt to ground unity amongst women. The most consistent form of anti-essentialism, then, which developed in the 1990s, denies that any features - natural or social - are common to all women, who are fully socially and corporeally diverse.

The increasingly radical rejection of essentialism prompted a counter-tendency within feminist thought, however, emphasising the neglected importance and political potential of essentialism. Feminists became increasingly concerned that accusations of essentialism often silenced thinkers, condemning their arguments out of hand. Naomi Schor, famously, complained that these accusations had become 'the prime idiom of intellectual terrorism and the privileged instrument of political orthodoxy ... endowed ... with the power to reduce to silence, to excommunicate, to consign to oblivion' ${ }^{\mathrm{x}}$ This prompted a reconsideration of whether essentialism might be philosophically or politically fruitful. Notably, feminist rejection of essentialism had posed several interwoven problems. Firstly, it had 'cast doubt on the project of conceptualizing women as a group'. ${ }^{\mathrm{i}}$ By denying women any shared features, anti-essentialism seemed to imply that there is nothing in virtue of which women could rightly be identified as forming a distinct social group. This undermined feminism as a critique of existing society, insofar as this critique is premised on the claim that women constitute a distinctly disadvantaged or oppressed social group. Anti-essentialism appeared also to have undermined feminist politics: if women do not share any common social 
location, then they cannot be expected to mobilise around any concern at their common situation, or around any shared political identity or allegiance. Thus, anti-essentialism seemed to undermine feminism both as social critique and as a political movement for social change.

Faced with these problems, 'anti-anti-essentialists' reconsidered how far some form of essentialism might be necessary for feminist social criticism and political activism. One of the most important strands in this reconsideration has been 'strategic' essentialism: the defence of essentialism not as a descriptive claim about social reality, but merely as a political strategy. In the next section, I will argue that strategic essentialism is unstable: although it attempts to avoid endorsing essentialism as a description of social reality, it ultimately remains forced to rely on descriptive essentialism to support its claim to political efficacy. I will then assess how a similar instability infiltrates Iris Young's suggestive attempt to reconceive women as a 'series', an attempt which nonetheless paves the way for my subsequent argument that women might productively be reconceived as having a genealogy.

\section{Strategic and descriptive essentialism}

Despite their concern to reappraise the political fertility of essentialism, few 'anti-antiessentialists' have sought to reinstate the belief in shared social characteristics common to all women. Rather, anti-anti-essentialists have tended to defend essentialism by arguing that it can take multiple forms, some more complex and subtle - and defensible - than its familiar ones. ${ }^{\text {xii }}$ In particular, it has been argued that essentialism need not take the form of a descriptive claim about social reality. According to 'strategic' essentialism, which became increasingly popular in the later 1980s and 1990s, feminists should acknowledge that essentialism is descriptively false in that it denies the real diversity of women's lives and social situations. ${ }^{\text {xiii }}$ Nonetheless, in delimited contexts, feminists should continue to act as if essentialism were true, so as to encourage a shared identification among women that enables 
them to engage in collective action. To take a controversial example, many of the bold statements in Luce Irigaray's later work have often been construed as strategically essentialist. In Thinking the Difference, she claims that women share certain bodily rhythms which give them a deep attunement to nature, and which mean that women are particularly adversely affected by ecological disasters such as the Chernobyl accident. ${ }^{\text {xiv }}$ It seems plausible to think that, rather than attempting to describe women as they really are, Irigaray is encouraging women to think that they suffer particularly from environmental problems, as a strategic identification that will galvanise them to collectively resist ecological degradation.

An objection immediately arises to this strategic essentialist position. Any political strategy is effective only inasmuch as it allows agents to recognise and intervene into the real social events, processes, and forces which make up the social field. But it seems reasonable to think that a strategy can be effective, in this sense, only insofar as it embodies an accurate understanding of the character of social processes. This implies that a strategy of affirming fictitious commonalities amongst women will fail to facilitate effective action given a world where women do not really have any common social characteristics or locations. Rather, such a strategy appears destined to mislead women into fighting against difficulties which are either non-existent or - more likely - really affect only some privileged subgroup of women.

This objection can be resisted, however, as it (implicitly) is by Denise Riley in 'Am I That Name?'. Riley claims that 'it is compatible to suggest that "women" don't exist - while maintaining a politics of "as if they existed" - since the world behaves as if they unambiguously did' ${ }^{\mathrm{xv}}$ That is, for Riley, the fiction that women share a common social experience is politically effective because the social world actually does treat women as if they comprise a unitary group. Riley accepts that women are not a unitary group and that the socially prevalent idea that they are unified is false. Nevertheless, this false idea informs and organises the practices and institutions which shape women's experiences, so that those - 
very different - experiences become structured by essentialist assumptions. A strategy of affirming fictitious commonalities therefore will be effective given this world in which (false) descriptive essentialist assumptions undergird women's social existence.

Riley's argument has a problem, though: she cannot consistently maintain both that women's social experience is fully diverse and that this experience is uniformly structured by essentialist assumptions. If essentialism informs and organises the structures that shape women's social experience, then this experience will be organised according to certain shared models and will acquire certain common patterns and features. More concretely, the idea that women are a homogeneous group will structure social institutions so that they position all women homogeneously, leading to (at least considerable areas of) shared experience. Thus, Riley (and other strategic essentialists) may be right that essentialist constructions are socially influential, but they cannot, consistently with this, also maintain that descriptive essentialism is false. Furthermore, it is not obviously true that any uniform set of essentialist constructions informs all social experience. These constructions may all identify women as a homogeneous group, but they vary widely in their account of what women's homogeneous features consist in. Consequently, these constructions will influence social structures in correspondingly varying directions, against which no counter-affirmation of common experience can be expected to be effective.

Strategic essentialists, then, have attempted to resuscitate essentialism by arguing that it can take a merely political and non-descriptive form. But this attempt proves unsuccessful, because one cannot defend essentialism on strategic grounds without first showing that there is a homogeneous set of essentialist assumptions which exerts a coherent influence on women's social experience - which amounts to defending essentialism on descriptive grounds (as well). Advocates of essentialism therefore need to show that it accurately describes social reality. Here, though, critics can retort that essentialism is descriptively false, 
since women do not even share any common mode of construction by essentialist discourses. Yet this retort reinstates the problem of anti-essentialism: its paralysing effect on social criticism and political activism. Strategic essentialism has not resolved this problem, for it has not stably demarcated any merely political form of essentialism from the descriptive essentialism which critics have plausibly condemned as false and oppressive.

\section{Women as a series}

To resolve the problems posed by anti-essentialism, feminist philosophers need to oppose essentialism as a descriptive claim - that is, to recognise the diversity of women's lives and social characteristics - and yet to continue to identify women as a distinctive (and distinctly disadvantaged) social group. This conjunction of anti-essentialism with feminist social ontology appears difficult to achieve, but could be accomplished if we reconceive women as a social group of some specifically non-unified type. Iris Marion Young takes this step in her paper 'Gender as Seriality'.

Young urges us to reconceive women as a series, where a series is a kind of group that is non-unified: 'vast, multifaceted, layered, complex and overlapping' ${ }^{\text {xi }}$ Employing the terminology of Jean-Paul Sartre's Critique of Dialectical Reason, Young distinguishes series from groups in the strict sense: the latter are collections of individuals who mutually recognise significant areas of shared experience and orientation to common goals. In contrast, membership in a series does not require members to share any attributes, goals, or experience. Instead, the members of a series are unified, passively, through their actions being constrained and organised by particular structures and constellations of material objects. Women, for example, are passively positioned in a series by the particular cluster of gender rules and codes which infuse everyday representations, artefacts, and spaces. Young's understanding of 
women as assembled into a 'series' allows her to deny women any common identity or characteristics, by arguing that they take up the constraints of gender structures in variable ways, within the contexts of entirely different projects and experiences. At the same time, Young can consistently claim that women retain the broad group status of a series insofar as the same set of 'feminising' structures remains a background constraint operative upon them all. Having secured women the status of a determinate social group - in this broad, nonunified, sense - Young concludes that it is possible for women to become conscious of their group status and so to become motivated into co-operating together politically.

Unfortunately, Young's approach has a drawback which is structurally similar to that of strategic essentialism: her defence of women's group status tacitly reinscribes the descriptive essentialism from which she explicitly distances herself. Although she denies that women share a common experience or identity, she does maintain that all women's activities and lives are 'oriented around the same or similarly structured objects [and] ... realities'. xvii From Young's perspective, there must be some features which unify these social structures and realities such that they can be said to co-operate in constituting women as a single, distinct, gender. As Young says, it is from the sameness of the objects structuring women's activities that the 'loose unity of the series ... derives'. Although, as she admits, the content of these objects and realities varies contextually, she still maintains that, despite their diversity, these realities share certain unifying characteristics. In particular, for Young, they all embody the expectation, firstly, of normative heterosexuality - which, she claims, 'constitute[s] women cross-culturally'xviii - and, secondly, of a sexual division of labour - the content of which, Young observes, 'varies with each social system, [although in each case] a division of at least some tasks and activities by sex appears as a felt necessity ${ }^{\text {xix }}$. Of course, she also insists that women experience these expectations differently given their diverse situations and activities. Yet the claim that these expectations organise the realities of all 
women's lives is itself ambiguous. Insofar as all women's lives are organised by a sexual division of labour, the content of this division varies widely, as Young herself admits. Likewise, the meaning of heterosexuality is highly varying (although, as a minimum, normative heterosexuality expects women to desire men, the meaning of this expectation will vary greatly relative to changing conceptions of masculinity and of desire, sexuality, and their social significance). So, Young's claim is plausible only if it acknowledges that the expectations which ultimately organise all women's lives are themselves varied; but, consequently, these expectations cannot be said to unify the structures by which women are serially positioned.

Young, however, needs to identify this unity because she can only retain a coherent feminine gender by arguing that, although women have no common features, there are common features - common expectations - organising all the social realities which constrain women's lives. Hence she has to maintain, for example, that normative heterosexuality has a universal, cross-cultural, meaning. This brings Young into a difficulty parallel to that of the strategic essentialists - she continues, ultimately, to rely on a descriptive form of essentialism, insofar as she has to affirm that there are certain universal norms which constitute all women as women (even though women do not share a common experience of those norms). Young's residual essentialism can be traced back to the Sartrean framework from which she derives her concept of a series. Sartre insists that series should not be equated with groups in the strict, unified, sense. Groups in the strict sense involve shared goals and experience, so that series count as groups only in a broad or, as Sartre puts it, 'neutral' sense. ${ }^{\mathrm{xx}}$ Yet the reason why Sartre continues to identify series as groups in this broad sense is because he regards series as self-alienated versions of strict, unified, groups. For Sartre, series are self-alienated groups in that their unity is located outside them, in the objective artefacts or structures by which their members are constrained and organised. ${ }^{\text {xxi }}$ Thus, from Sartre's 
perspective, series only count as groups at all to the extent that they remain unified, albeit in a relatively indirect, exteriorised, way.

Young's Sartrean concept of the series proves inadequate to the task which she wishes it to play: that of enabling her to reconceive women as a specifically non-unified type of social group. Despite this failing, the importance of Young's argument lies in her more basic insight that reconceiving women as a non-unified type of social group could surmount the problems generated by feminist critiques of essentialism. I therefore propose to develop Young's insight, by jettisoning the idea that women constitute a series, and instead rethinking women as having a genealogy - that is, as constituting a group which is internally diverse, and yet remains a group in virtue of having a complex history composed of multiple, overlapping, threads of interpretation.

\section{Women as having a genealogy}

In this section, I will argue that an appropriation of the concept of genealogy can provide a way to reinstate the idea that women comprise a distinct social group even in the absence of any common properties that constitute them all as women. Several prominent feminist thinkers have already drawn on the concept of genealogy: for example, in Gender Trouble Judith Butler proposes to outline a genealogical understanding of what it means to be a woman. ${ }^{\text {xii }}$ Similarly, Moira Gatens praises the 'project of charting a genealogy of the category "woman" or "women". On this approach "women" itself is understood to have a history, a genealogy, a "line of descent” ... a genealogical approach asks: how has “woman"/"women" functioned as a discursive category throughout history?' xxiii These approving references to genealogy by Butler and Gatens imply that ideas of femininity should be understood as historically constructed in multiple, shifting, ways, their fluctuations in meaning registering changes in social relations of power. In this, though, Butler and Gatens 
appear concerned to trace the history of the concept 'woman' rather than the history of women themselves. Yet the concept of genealogy can only provide a way of grasping women as a distinct (albeit non-unified) social group if women themselves have a genealogy - that is, to anticipate, if their experiences and psychologies are shaped in overlapping and historically interconnected ways. Thus, any anti-essentialist appropriation of the concept of genealogy must clarify the relationship between the genealogy of ideas concerning femininity and the genealogy of women themselves.

To do this we can return to Nietzsche, from whom both Butler and Gatens derive their concepts of genealogy. Gatens draws deliberately upon Nietzsche, ${ }^{\text {xiv }}$ and, although Butler draws more explicitly upon Foucault than Nietzsche, she herself repeatedly stresses that Foucault's practice of genealogical enquiry is deeply indebted to his interpretation of the concept of genealogy in Nietzsche. ${ }^{\mathrm{xxv}}$ In the Genealogy of Morality (1887), Nietzsche sketches a distinctive form of historical enquiry which traces how historically changing concepts - such as 'guilt', 'duty', 'community', 'good' and 'evil' - shape lived social experience. He also traces how the power relations that are at work within people's social experiences lead them to reshape those concepts in turn. In explicating Nietzsche's approach, I shall draw on Foucault's presentation of it in his important methodological essay 'Nietzsche, Genealogy, History' (1971). ${ }^{\text {xxvi }}$

In the Genealogy, Nietzsche denies that any common characteristics unite all the institutions, practices, and beliefs normally classified under the rubric of morality. Nietzsche thus adopts an anti-essentialist approach to morality, taking its constituent practices and beliefs to be highly diverse, ${ }^{\text {xxvii }}$ and to fall under the single rubric of morality solely in virtue of belonging within a distinctive history. Foucault stresses that for Nietzsche, this history is not to be studied through 'traditional' modes of historical enquiry, which misleadingly presuppose an underlying unity amongst moral phenomena. Instead, the history of morality 
should be approached through a novel mode of enquiry - 'genealogy' - which attends to the fluctuating and internally heterogeneous character of its object of study. ${ }^{\text {xxiii }}$ In particular, the genealogist is to trace how some contemporary practice (for example, punishment) or experience (for example, guilt) has arisen from an indefinitely extended process whereby earlier forms of that practice or experience have become reinterpreted by later ones. Thus, the genealogist treats any historically arisen phenomenon as the reinterpretation of a pre-existing phenomenon, upon which the new interpretation 'has impressed ... its own idea of a use function' ${ }^{\text {xxix }}$ A genealogy takes shape as a practice or experience becomes subjected to repeated reinterpretations which impact upon its 'meaning [Sinn], purpose and expectation'. ${ }^{\mathrm{xx}}$

According to Nietzsche, any reinterpretation must install itself by accommodating, as far as possible, the meanings embedded in the pre-existing phenomenon, ${ }^{\mathrm{xxi}}$ though necessarily it sheds the elements of those meanings which remain incompatible with its own agenda. This makes reinterpretation a conflictual, agonistic, process, in which present forces strive actively to take over recalcitrant elements of the past. The outcomes of these conflictual activities of reinterpretation are always variable and contingent, as Foucault particularly stresses. ${ }^{\text {xxii }}$ A key point, though, is that any practice or experience which succumbs to reinterpretation has itself already taken shape as the sedimentation of earlier layers of interpretation. No common core of significance persists through all these layers of interpretation. Because incompatible elements of meaning become shed upon each occasion of reinterpretation, a process of attrition takes place through which earlier layers of meaning gradually get eroded away altogether. For example, he traces how the experience of bad conscience becomes reinterpreted by Christianity - and consequently re-experienced, relived - as sinfulness. ${ }^{\text {xxxiii }}$ In similar fashion, the earlier meanings of all the constituents of the 
institution of morality are gradually and continuously being etched out by new acts of reinterpretation. ${ }^{\text {xxiv }}$

Nietzschean genealogy, then, traces how concepts such as 'guilt' and 'evil' undergo varying interpretations, where these interpretations - and the concepts which they organise continually reshape our experience and practices. To study these experiences and practices genealogically is to situate them within a particular group - for example, the group 'morality' - not because of any essential characteristics which they share with all the group's other members, but just because each member in the group stands in the appropriate historical relationship to (one or more of) the others. More specifically, a set of such items is grouped together only in virtue of the fact that each takes shape through the reinterpretation of one or more of the others. The items in this group need not have anything in common, but need only be connected together through a complex process of historical drift in meaning. From a Nietzschean perspective, any set of concepts, experiences, or practices which become related in this overlapping way has a genealogy.

Nietzsche's idea that any chain of historically overlapping phenomena has a genealogy makes it possible to reconceive women as a determinate social group without reverting to the descriptive essentialist claim that all women share a common social position or mode of experience. Any such 'genealogical' analysis of women must start by recognising that concepts of femininity change radically over time, and that these changing concepts affect women's social position and lived experience. In particular, a genealogical analysis of women is premised on the view - articulated in Judith Butler's work - that women only become women, or acquire femininity, by taking up existing interpretations and concepts of femininity. As Butler puts it, taking on a gender involves finding 'a contemporary way of organising past and future cultural norms, a way of situating oneself in and through those norms, an active style of living one's body in the world' ${ }^{\mathrm{xxv}}$ As this remark suggests, the 
taking on of femininity consists not merely in a process of mental identification with existing concepts, but - more fundamentally - in a process of acquiring a feminine way of living one's body, of inhabiting one's physiology. Moreover, this does not entail being passively moulded by exterior cultural forces; rather, women become women through active appropriation and personalising of inherited cultural standards.

Butler also stresses, though, that each appropriation of existing standards concerning femininity effects a more or less subtle alteration of their meaning: individuals always 'interpret received gender norms in a way that organises them anew'. In actively appropriating existing standards, individuals necessarily adapt them with reference to the varied contexts, power relationships, and personal histories within which they are located. Received meanings regarding gender continuously become subjected to practical reinterpretation, reinterpretation which individuals undertake with tacit reference to their differing personal and cultural experiences. That the meaning of femininity undergoes incessant modification implies that it is considerably less unified than one might, at first glance, assume. There is no unitary meaning of femininity on which all women agree: for, even although all women may identify with femininity, they will always understand and live their femininity in different ways. Nonetheless, according to a genealogical approach, all women remain identifiable as women. Although they do not share any characteristics simply qua women, in each case they become feminine by reworking pre-established interpretations of femininity with reference to their specific situations. In virtue of carrying out this reworking, each woman becomes located within a historical chain of women, a chain composed of all those who have successively engaged in reinterpreting the meaning of femininity. All women thus become located within an ongoing chain of practice and reinterpretation, which brings them into complex filiations with one another. The genealogy that arises through this process is not only a history of concepts of femininity, but is also, 
simultaneously, a history of women themselves, as individuals who become women by taking on and adapting existing concepts of femininity.

Since genealogical reinterpretation is an agonistic process, each reinterpretation of femininity must overlap in content with the interpretation that it modifies, preserving some elements of that pre-existing interpretation while abandoning others. Through the resulting process of attrition of meanings, each woman will find herself in a series of gradually diminishing connections with women of previous generations. Moreover, within a single generation, each woman's reinterpretation of femininity will overlap in content, to varying degrees, with other women's reinterpretations; these overlaps must arise, insofar as all these women are engaged in reworking the same set(s) of pre-existing meanings. An understanding of women as having a genealogy thus entails that, instead of forming a unitary group, they are connected together in complex ways and to varying degrees; and, in particular, that they are linked by their partially and multiply overlapping interpretations of femininity.

This genealogical conception of women might be criticised on two, closely interrelated, grounds. Firstly, one might object that it is not ultimately very different from Young's idea that women form a series. Just as Young preserves women's status as a group by arguing that their lives are shaped by a universal set of normative expectations, likewise the genealogical view argues that women participate in a unitary history. This history is unitary in virtue of the continuity between its constituent phases, a continuity which arises insofar as every reinterpretation of femininity - and every re-experiencing of womanhood builds upon, and so retains a partial overlap with, pre-existing interpretations and experiences. But, just as the expectations that Young believes to organise women's lives are more plausibly seen as diverse than singular in content, likewise the history of femininity and women might be most plausibly seen as discontinuous. Arguably, the genealogical view overemphasises overlaps and continuities between different interpretations and experiences of 
femininity, ignoring the deep chasms which regularly open up between understandings of femininity - the breaks in the chain of (re)interpretation. This objection takes on special importance because such discontinuities will typically reflect exactly those asymmetries of power which appear to impede the possibility of women achieving any solidarity as a group.

Against this objection, I suggest that the strength of the genealogical approach is that it can accommodate the reality of historical discontinuity alongside that of continuity. According to this approach, successive modifications in the meaning of femininity necessarily build upon one another, leading to the formation of distinct historical patterns of interpretation of femininity emerge, which branch apart from one another in particular directions. This branching, moreover, will typically follow along differentials in power (which lead women to modify the meaning of femininity in particular ways). As the branching occurs, the process of attrition whereby earlier elements of meaning get worn away will ensure that quite separate cultures of femininity emerge. Women located within these separate cultures - cultures that occupy different positions within relations of power - will have ceased to share any experience as women, even though they all identify themselves as feminine. In such cases, women remain connected together only indirectly - via the long chains of overlapping meaning and practice which span the gulf between them. Thus, a genealogical approach itself implies the inescapability of both continuities and discontinuities within the history of femininity.

As a consequence of these discontinuities in the meaning of femininity, women must be considered not merely as an internally diverse group but also, more strongly, as a group fractured and torn apart by divisions in power. Recognising this, for instance, Butler refers to the incessant occurrence of 'rifts among women over the content of the term' (that is, 'woman'). ${ }^{\text {xxxi }}$ Yet, however severe this rifting, it remains compatible with women's existing as a distinctive social group. This is because women remain defined by a single history, even 
though this history is extremely complex and follows multiple branches. Women's history should be understood on the model of a tree, which remains singular even as it continually ramifies into innumerable (multiply interwoven) branches. Properly understood, then, the genealogical view avoids reinstating descriptive essentialism because it holds that what unites women - their history - is internally complex. At the same time, this view insists that this complex history remains singular, and hence does constitute women as a group whose history, and consequent social positions, can be identified as distinctively oppressive.

This rethinking of women and femininity as having a genealogy opens up the possibility of an anti-essentialism which supports, rather than paralyses, feminist politics. To the extent that women remain a social group (united in their participation in a single history), they can mobilise together in pursuit of distinctive concerns. Nonetheless, since women's history is internally complex, and women's concerns are correspondingly diverse, the only mode of collective activity appropriate for women must be similarly diversified - allowing women to pursue concerns which are specific to them as women, yet which differ from one another as well. This mode of political activity must, in addition, be capable of accommodating deep rifts and divisions amongst women, by providing them with the space for difficult negotiation over their divisions. These two conditions suggest that a coalitional politics is uniquely appropriate for women. This is, indeed, the political practice generally endorsed by advocates of a genealogical approach. ${ }^{\text {xxxvii }}$ But what is a coalitional feminist politics?

Coalitions may be said to arise when different women, or sets of women, decide to act together to achieve some determinate objective, while yet acknowledging the irreducible differences between them and the often highly divergent concerns which motivate them to pursue this objective. On the basis of the idea that women have a genealogy, we can explain why women might, despite these irreducible differences, reasonably seek to mobilise together 
on such a coalitional footing. Firstly, each woman's historically shaped experience inevitably overlaps in content with that of at least some other women, which gives them areas of commonality that they might reasonably seek to transform together, despite being very different in other respects (and so approaching these objectives from quite disparate perspectives). Secondly, in each woman's case, there will be many other women with whose experience her own has no direct overlap, and with whom she is only indirectly connected (through the whole web of overlapping relations between women). These might typically be women to whom she stands in a deeply asymmetrical power relationship. Nonetheless, there might be many cases in which she could reasonably seek to act in concert with those women, because she could expect improvements in either of their situations to indirectly have positive repercussions for the other. Since women remain connected indirectly by long chains of reinterpretation of femininity, an improvement in the situation of any women should impact positively upon those women whose interpretations of femininity overlap, so that, through a kind of wave effect, even the women at furthest remove could anticipate some indirect benefit. Those women might, at least, be benefited in the sense that any change exposes the meaning of femininity as contingent and malleable, making it easier to undertake transformative reinterpretations of the meanings of femininity which have become sedimented within their own cultures. Certainly, such potential gains would be obstructed if privileged groups of women respond to improvements in their situations in ways that reinforce hierarchies between women. Nonetheless, a genealogical conception of women and femininity at least suggests ways to reflect upon the spectrum of motivations which might lead women to enter coalitions, different motivations which correspond to women's varying degrees of cultural overlap and connectedness. 


\section{Conclusion}

I have attempted to reassess feminist debates around essentialism in a way that brings out the philosophical, ethical, and political significance of the questions they have raised. As I have traced, these debates pose a central, and widely acknowledged, dilemma: essentialism is plausibly seen as false as a descriptive claim about the social reality of women's lives, yet appears necessary to feminist politics and social criticism. I have argued that this dilemma cannot be solved by endorsing essentialism merely as a political strategy, since essentialism can only be defended on strategic grounds if it is held to be descriptively true as well. Instead, the dilemma should be solved by accepting that essentialism is descriptively false, but reconceiving women as a specifically non-unified sort of social group. From this perspective, I have suggested that we might rethink women, and femininity, as having a genealogy. This provides a way to identify women as a definite social group without falsely attributing to them any common characteristics that constitute them all as women.

According to my argument, every woman becomes a woman by taking over and reinterpreting pre-existing cultural constructions of femininity, constructions which in turn exist as a result of preceding activities of reinterpretation, so that all these interpretations of femininity - and all the women who produce and experience them - come to belong within overlapping chains. These chains make up a unique - albeit complex and multiply branching - history within which all women are situated. Thus, although women do not share any common characteristics, they are defined as a group by their participation in this history. This opens up various ways in which women might become motivated to engage in collective action organised coalitionally. I suggest, then, that the idea that women have a genealogy overcomes the dilemma posed by feminist critiques of essentialism, explaining how - despite their lack of common characteristics - women can still exist as a determinate group, susceptible to collective mobilisation. ${ }^{\text {xxxviii }}$ 
'I take the locution 'anti-anti-essentialism' from Cressida Heyes, Line Drawings: Defining Women Through Feminist Practice (Ithaca: Cornell University Press, 2000), pp. 67-72.

${ }^{i i}$ Butler, Gender Trouble (London: Routledge, 1990), p. 5.

iii Spivak, 'In a Word: Interview' with Ellen Rooney, in N. Schor and E. Weed (eds.), The Essential Difference (Bloomington: Indiana University Press, 1994), p. 159.

${ }^{\text {iv }}$ Heyes, Line Drawings, p. 37. Charlotte Witt argues that feminist critiques of essentialism have four similar targets: (1) the metaphysical belief that gender and sex are core attributes of the self; (2) biological determinism; (3) the belief that the word 'feminine' has a fixed meaning; (4) the practice of making false generalisations about women; see Witt, 'AntiEssentialism in Feminist Theory', in Philosophical Topics 23: 2 (1995), pp. 321-344.

${ }^{\mathrm{v}}$ Naomi Schor stresses that essentialism and universalism differ in 'This Essentialism Which Is Not One: Coming to Grips with Irigaray', in N. Schor and E. Weed (eds.), The Essential Difference (Bloomington: Indiana University Press, 1994), p. 24. One might, for instance, argue that there are certain characteristics which all women share, but which are accidental rather than essential (that is, these features could be changed without women thereby ceasing to be women) - such as, perhaps, the feature of being disempowered relative to men. Yet though universal features need not be essential, essential properties are necessarily universal, hence 'essentialism' and 'universalism' are generally assimilated in feminist discussion.

${ }^{\mathrm{vi}}$ For a classic socialist feminist critique of radical feminism, see Lynne Segal, Is the Future Female? (London: Virago, 1987).

${ }^{\text {vii }}$ See, respectively, Nancy Hartsock, Money, Sex, and Power: Toward a Feminist Historical Materialism (New York: Longman, 1983); Catherine MacKinnon, 'Feminism, Marxism, Method and the State: An Agenda for Theory', Signs 7 (1982), pp. 515-44; Carol Gilligan, In 
a Different Voice (Cambridge, Mass.: Harvard University Press, 1982). Gilligan has

subsequently revised her ethical theory to mitigate the exclusive tendencies critics detected in it: see J. M. Taylor, Carol Gilligan, and A. M. Sullivan, Between Voice and Silence: Women and Girls, Race and Relationship (Cambridge, Mass.: Harvard University Press, 1996).

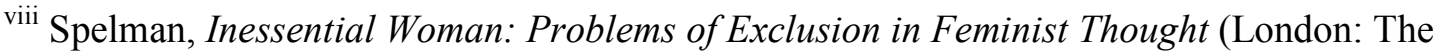
Women's Press, 1988).

${ }^{\text {ix }}$ See Butler, Gender Trouble; Gatens, Imaginary Bodies (London: Routledge, 1996); Grosz, Volatile Bodies: Toward a Corporeal Feminism (Bloomington: Indiana University Press, 1994).

${ }^{\mathrm{x}}$ Schor, 'This Essentialism Which Is Not One', p. 42.

${ }^{x i}$ Iris Marion Young, 'Gender as Seriality: Thinking about Women as a Social Collective', Signs 19: 3 (1994), p. 713.

${ }^{x i i}$ See, especially, Schor, 'This Essentialism Which Is Not One', p. 43.

xiii 'Strategic' essentialism is, of course, primarily associated with Spivak, who coined the term in 'Feminism, Criticism and the Institution', in Thesis Eleven 10/11 (1984/5), pp. 175187. Spivak, however, introduced strategic essentialism in relation to subaltern studies: her term was taken up within feminist contexts in ways she did not intend.

${ }^{\text {xiv }}$ Irigaray, Thinking the Difference: For a Peaceful Revolution, trans. K. Montin (London: Athlone Press, 1994), pp. 24-26.

${ }^{\mathrm{xv}}$ Riley, 'Am I That Name?': Feminism and the Category of 'Women' in History (London: Macmillan, 1982), p. 112.

${ }^{\text {xvi }}$ Young, 'Gender as Seriality', p. 728.

xvii Ibid., p. 728; emphasis added.

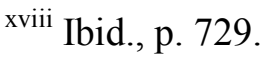


${ }^{\text {xix }}$ Ibid., p. 730.

${ }^{\mathrm{xx}}$ Sartre, Critique of Dialectical Reason, Vol. I: Theory of Practical Ensembles, trans. A. Sheridan-Smith (London: New Left Books, 1976), p. 256.

xxi Ibid., pp. 258-259.

xxii Butler, Gender Trouble, p. 5.

xxiii Gatens, Imaginary Bodies, p. 76.

${ }^{\text {xxiv }}$ Ibid., p. 76-77.

${ }^{\mathrm{xxv}}$ See, especially, Butler, Subjects of Desire: Hegelian Reflections in Twentieth-Century France (New York: Columbia University Press, 1987), pp. 226-228; Gender Trouble, pp. 20 $21,150,161$.

${ }^{\text {xxvi }}$ Foucault, 'Nietzsche, Genealogy, History' is reprinted in J. Richardson and B. Leiter (eds.), Nietzsche (Oxford: Oxford University Press, 2001), pp. 341-359. On the importance of this paper for Foucault's subsequent work, see, inter alia, Michael Mahon, Foucault's Nietzschean Genealogy: Truth, Power, and the Subject (Albany: SUNY Press, 1992). ${ }^{\text {xxvii }}$ See Raymond Geuss, 'Nietzsche and Morality', in Morality, Culture and History: Essays on German Philosophy (Cambridge: Cambridge University Press, 1999), pp. 167-169.

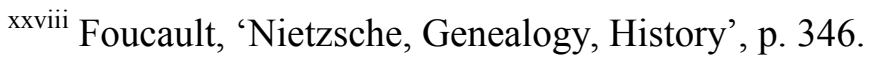

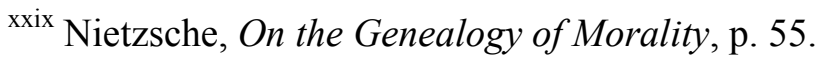

${ }^{\mathrm{xxx}}$ Ibid., p. 57.

${ }^{\text {xxi }}$ As Geuss explains, Nietzsche's conflictual model implies that no reinterpretation will ever 'encounter ... just a tabula rasa, but a set of actively structured forces, practices etc. which will be capable of active resistance' (Geuss, 'Nietzsche and Genealogy', in Morality, Culture, and History, p. 13). This resistance ensures that new interpretations will 'not in general be so fully successful that nothing ... remains' of the pre-existing meanings (p. 11). 
xxxii Foucault, 'Nietzsche, Genealogy, History', p. 347-348.

xxxiii Nietzsche, On the Genealogy of Morality, p. 100.

xxxiv This insight underlies Nietzsche's claim that genealogists trace the 'descent' (Herkunft)

of phenomena rather than their putative 'origins' (Ursprünge). Because any historical

phenomenon arises gradually through the concatenation of an indefinite multiplicity of

events, there is no definitive point at which that phenomenon can be said to have 'originated'

(see Nietzsche, On the Genealogy of Morality, pp. 4-7; Foucault, 'Nietzsche, Genealogy,

History', pp. 342-43).

${ }^{\text {xxxv }}$ Butler, 'Variations on Sex and Gender: Beauvoir, Wittig and Foucault', in S. Benhabib

and D. Cornell (eds.), Feminism as Critique (Minneapolis: University of Minnesota Press, 1987), p. 131.

xxxvi Butler, 'Contingent Foundations: Feminism and the Question of "Postmodernism"” in S. Benhabib et al. (eds.), Feminist Contentions: A Philosophical Exchange (London: Routledge, 1995), p. 50.

${ }^{\text {xxxvii }}$ See, for example, Nancy Fraser and Linda Nicholson, 'Social Criticism Without Philosophy: An Encounter Between Feminism and Postmodernism,' in L. Nicholson (ed.), Feminism/Postmodernism (London: Routledge, 1990), p. 35.

xxxviii This paper is a substantially revised version of my earlier article, 'On the Genealogy of Women: Against Essentialism in Feminist Philosophy', in Third Wave Feminism: A Critical Assessment, ed. Stacy Gillis, Gillian Howie, and Becky Munford (London: Palgrave, forthcoming). I thank Gillian Howie, Vrinda Dalmiya, and the anonymous referee for the Journal of Moral Philosophy for their helpful comments on earlier versions of this paper. 